\title{
Effect of Organic Manures in the Management of Colletotrichum capsici and Meloidogyne incognita in Capsicum (Bell Pepper)
}

\author{
Pillakathupu Gopi Krishna*, Mullangi Pranitha and Sobita Simon \\ Department of Plant Pathology, Sam Higginbottom University of Agriculture, Technology and \\ Sciences, Prayagraj, India \\ *Corresponding author
}

Capsicum annum L. (Bell pepper) belongs to the family Solanaceae is an important fruit vegetable constituent that is used in many foods, adding flavor, colour, and is rich source of 'Vitamin C'. An experiment was conducted at the Department of Plant

Keywords

Colletotrichum capsici,

Meloidogyne incognita, Organic Amendments

Article Info

\section{Accepted:}

12 April 2021

Available Online:

10 May 2021 Pathology, SHUATS, Prayagraj, U.P. during 2018-2019 to observe the effect of organic manures (viz. $\mathrm{T}_{1}$-Goat manure, $\mathrm{T}_{2}-\mathrm{FYM}, \mathrm{T}_{3}$ - Neem @ $500 \mathrm{gm}$ per $10 \mathrm{~kg}$ soil in combination with $250 \mathrm{gm}$ of $\mathrm{T}_{4}$-Neem+G.M, $\mathrm{T}_{5-} \mathrm{Neem+FYM}$ ) against disease incidence of Colletotrichum capsici and Meloidogyne incognita in Capsicum. The organic amendments were incorporated in the pot 15 days before transplant of capsicum. The seedlings of 40 days of capsicum were transplanted prior to inoculation with $2 \mathrm{gm}$ mycelium mat of Colletotrichum capsici per each pot. Seven days after transplant Meloidogyne incognita were inoculated @ 2 larvae per gm of soil in each treatment. Each treatment were replicated five times. Observations were recorded on disease incidence of Colletotrichum capsici at 30, 60, 90 DAT, the root gall population also observed at 90 DAT under pot condition. Among the treatments at 30 d.a.i. the percentage disease incidence of Colletotrichum capsici on the leaf was significantly reduced in $\mathrm{T}_{3}(2.93), \mathrm{T}_{4^{-}}$(3.58) as compared with $\mathrm{T}_{5^{-}}$(4.37), $\mathrm{T}_{1^{-}}$(4.73), $\mathrm{T}_{2^{-}}$(4.95) and control (12.34). The root gall population of Meloidogyne incognita was significantly reduced in Neem (17.60), Neem + FYM (37.00) as compared with other treatments including control.

\section{Introduction}

Capsicum is affected by several fungal, bacterial and viral diseases, of which capsicum anthracnose causes considerable damage, inflicting severe quantitative and qualitative losses. The antracnose symptoms can occur on leaves, stems, and both pre- and post-harvest fruits. Typical anthracnose symptoms on chilli fruit include sunken necrotic tissues, with concentric rings of acervuli (Agrios 2005). Severely infected leaves fall off leading to defoliation. The infection of growing tips lead necrosis of branches which progresses backward on the diseased branches (Dieback Stage).The die 
back may kill the whole plant (Kumar and Bhaskaran, 2007).

Black dots (acervuli) are formed all over the necrotic surface of the affected twigs later on. The Colletotrichum capsici is seed, soil and air borne disease. On fruits, dark brown to black sunken spots, circular or angular shape with concentric rings of acervuli that are often wet and produce pink to orange conidial (spores) masses are evident. This disease is a severe problem on mature fruits, causing severe losses in field, transportation and storage due to both pre- and post-harvest fruit decay (Hadden and Black, 1989, Bosland and Votava, 2003). The antracnose is prevalent in almost all major capsicum growing areas and it is reported to cause $25-48 \%$ loss in different parts of India (Datar, 1995; Fugro, 2000, Ekbote, 2001 and Rathore, 2006). Root knot nematode causes damage for several crops like capsicum, chilli, tomato, potato.Meloidogyne species are the most prominent family affecting vegetable crops(Williamson and Hussey et al.,1996).

They initiate a series of changes in the root, resulting in the formation of galls, commonly called as root knots. Nematodes are often identified as sedentary endo-parasites, but they need to be mobile to reach the root system (Bird 1961). Once the nematodes are at the root it, then pierces the hard tissues by using a biochemical process to gain entry into the vascular system (Giebel 1974).

Effect of organic manures FYM, Goat manure treated pots was significantly higher in plant height (James and Simon 2015). Meloidogyne spp. is the most serious plant-parasitic nematodes on a worldwide basis. Bell pepper (Capsicum annuum) is widely cultivated in Iran, both in greenhouse and on farm. Rootknot nematodes (RKNs) attack this crop and often impose a considerable loss (Ghaderi et al., 2012). Due to the wide host range and adaptability to varying environments, Meloidogyne incognita is spreading rapidly to lesion where it was not known previously. The different organic amendments viz., farm yard manure (FYM) (12.5 t/ha), neem cake (250 $\mathrm{kg} / \mathrm{ha})$, goat manure (12.5 t/ha), efficacy against capsicum anthracnose (Suji and Raj 2015). (Asiah 2006) reported that application of organic materials could increase yield productivity and reduce intensity of pest and disease.

The control of plant-parasitic nematodes with organic soil amendments especially with neem based materials have proved very effective (Akhtar 1999). (Reddy et al.,1993)effectively used $50 \mathrm{~g}$ neem $/ \mathrm{kg}$ soil to contol root-knot nematodes on capsicum, the changing numbers of the nematodes in the amendment soil. Population of Meloidogyne decreased with time in all the amendments and the unamended soil. Numbers of nematodes were significantly lower in the amended soil.

\section{Materials and Methods}

\section{Isolation of Colletotrichum capsici}

Isolation of antracnose was done following the procedure by Linu et al., (2017). Infected fruit specimens were collected from central research field SHUATS Allahabad. The fruit specimens were washed with tap water, the discolored parts cut into small pieces $(5 \mathrm{~mm})$, sterilized with $0.1 \% \mathrm{Hgcl}_{2}$ for two min and rinsed in sterilized water for three times and dried between folds of sterilized filter paper. The sterilized fruit pieces were transferred on PDA plates and incubated at room temperature for 5 days. Mycelial bits were transferred to sterile petridishes containing PDA; later it was purified by hyphal tip method and transferred to Potato dextrose agar (PDA) slants and pure cultures of the pathogens were maintained for further studies. Multiplication of pathogen was done by using potato dextrose agar media. 


\section{Preparation of Seedlings in Nursery}

It is propagated by seeds; fresh seeds are sown in 1metre well prepared nursery bed. By mixing with Goat manure in the soil. After 7 days of mixing goat manure capsicum seeds were sown by line at the depth of 1 to $3 \mathrm{~cm}$ and covered with 1 layer of soil. Next day sprinkler irrigation were given, germination of the seed was started at 7 days after sowing, the 40 days old seedlings are used for transplanted in the respective amendment pots.

\section{Collection of nematodes from infected Okra crop}

Root knot infected okra plants were collected from the central field of Sam Higgin bottom University of Agriculture, Technology and Sciences, Prayagaraj. Nematode infected okra crop were collected from the field after harvesting and root galls were washed free of adhering soil particles. Infected galls were cut into small pieces and graded in electrical grinder with little amount of water.

Amendment of organic manure and inoculation of pathogens

Before transplanting the plants of Capsicum Goat manure, FYM, Neem, Neem+G.M, Neem+FYM were taken@ 0500 gm were incorporated in $10 \mathrm{~kg}$ of soil in each pot and 5 pots were taken without organic amendments as control. Healthy 40 days seedlings are planted to each treated $10 \mathrm{~kg}$ capacity of pot carefully teasing apart the tangled mass of roots and keep the pots out of direct sunlight. Seven days after transplant the plants were inoculated with Colletotrichum capsici @ 2 gm mycelium mat to the rhizosphere area of capsicum. Seven days after transplant Meloidogyne incognita were inoculated @2 larvae per gm of soil in each treatment. Each treatment were replicated five times.
Observations were recorded on disease incidence of Colletotrichum capsici at 30, 60, 90 DAT, the root gall population also observed at 90 DAT under pot condition.

\section{Characteristics of Meloidogyne incognita}

Plants affected by Meloidogyne incognita presents above ground symptoms of water and nutrient stress, yellowing, wiliting, and stunting. Below ground galling on roots, bulbs, tubers is the typical symptom. Plant death may occur in high infestation level. The female is pear shaped about $1 \mathrm{~mm}$ long, with a sedentary habit, embedded in root tissues. Its pearl white body is almost completely filled by the ovaries. It does not form a cyst. The males have an ordinary worm like appearance.(Jepson, 1987)

\section{Disease intensity}

Per cent disease intensity was recorded at 30 , $60 \& 90$ days after incidence of Colletotrichum capsici.(Singh, 1988)

Per cent disease intensity/index was calculated by applying following formula

Disease intensity (\%)

Sum of all disease ratings

Total number of x
leaves/plant

The data presented in table 1.1. and depicted in figure 1.1.revealsthe response of effect of organic manures on Colletotrichum capsici disease incidence of capsicum at 30, 60, 90 DAI under pot conditions. Among the treatments at 30,60, 90 d.a.i. all the organic manures treated pots significantly reduced percentage disease incidence of Colletotrichum capsici on foliar as compared with control. 
Table.1 Rating Scale for disease intensity on foliage

\begin{tabular}{|c|c|}
\hline Gr.* & Description \\
\hline $\mathbf{0}$ & No symptoms on plant \\
\hline $\mathbf{1}$ & Less than $1-10$ per cent leaf area affected \\
\hline $\mathbf{3}$ & $11-25$ per cent leaf area affected \\
\hline $\mathbf{5}$ & Spots big; $26-50$ per cent leaf area affected \\
\hline $\mathbf{7}$ & $51-75$ per cent leaf area affected \\
\hline $\mathbf{9}$ & $>75$ per cent leaf area affected \\
\hline
\end{tabular}

Table.2 To evaluate the effect of organic manure on the disease intensity of Colletotrichum capsici at different days of intervals.

\begin{tabular}{|c|c|c|c|c|c|c|c|c|}
\hline S.No & Treatmens & 30DAT & $\begin{array}{c}\text { \% } \\
\text { inhibition }\end{array}$ & 60DAT & $\begin{array}{c}\text { \% } \\
\text { inhibition }\end{array}$ & 90DAT & $\begin{array}{c}\text { \% } \\
\text { inhibition }\end{array}$ & MEAN \\
\hline $\mathbf{T}_{\mathbf{0}}$ & Control & 12.34 & & 37.62 & & 84.32 & & 44.76 \\
\hline $\mathbf{T}_{\mathbf{1}}$ & Goat manure & 4.73 & 61.66 & 9.92 & 73.63 & 36.02 & 57.28 & 16.89 \\
\hline $\mathbf{T}_{\mathbf{2}}$ & FYM & 4.95 & 59.88 & 12.74 & 66.13 & 39.93 & 52.64 & 19.21 \\
\hline $\mathbf{T}_{\mathbf{3}}$ & $\begin{array}{c}\text { Neem leaf } \\
\text { manure }\end{array}$ & 2.93 & 76.25 & 6.46 & 82.82 & 27.98 & 66.81 & 12.46 \\
\hline $\mathbf{T}_{\mathbf{4}}$ & $\begin{array}{c}\text { Neem+Goat } \\
\text { manure }\end{array}$ & 3.58 & 70.98 & 8.12 & 78.41 & 31.65 & 62.46 & 14.45 \\
\hline $\mathbf{T}_{\mathbf{5}}$ & Neem+FYM & 4.37 & 64.58 & 9.58 & 74.53 & 35.98 & 57.32 & 16.64 \\
\hline & $\mathbf{F - t e s t}$ & $\mathbf{S}$ & & $\mathbf{S}$ & & $\mathbf{S}$ & & \\
\hline & $\mathbf{S .} \mathbf{E d} \mathbf{(} \mathbf{(})$ & $\mathbf{1 . 0 6 6}$ & & 1.875 & & 3.041 & & \\
\hline $\mathbf{C . D .}(\mathbf{P}=\mathbf{0 . 0 5})$ & 2.260 & & 3.976 & & 6.446 & & \\
\hline
\end{tabular}

Table.3 To evaluate the effect of organic manures on root gall population of Meloidogyne incognita in Capsicum

\begin{tabular}{|c|c|c|c|}
\hline \multirow[t]{2}{*}{ S.NO } & \multirow[t]{2}{*}{ Treatments } & \multicolumn{2}{|c|}{ Root-gall population after 90 DAI } \\
\hline & & Mean of five replicants & $\begin{array}{c}\% \text { reduction over } \\
\text { control }\end{array}$ \\
\hline $\mathrm{T}_{0}$ & Control(Nematode) & 85.00 & \\
\hline $\mathrm{T}_{1}$ & G.M+Nematode & 40.40 & 52.47 \\
\hline $\mathrm{T}_{2}$ & FYM+Nematode & 50.40 & 40.70 \\
\hline $\mathrm{T}_{3}$ & Neem+Nematode & 17.60 & 79.29 \\
\hline $\mathrm{T}_{4}$ & G.M+Neem+Nematode & 39.80 & 53.17 \\
\hline \multirow[t]{4}{*}{$\mathrm{T}_{5}$} & Neem+FYM+Nematode & 37.00 & 56.47 \\
\hline & F- test & \multicolumn{2}{|c|}{$\mathbf{S}$} \\
\hline & S. Ed. $( \pm)$ & \multicolumn{2}{|c|}{4.149} \\
\hline & C. D. $(P=0.05)$ & \multicolumn{2}{|c|}{8.796} \\
\hline
\end{tabular}


Fig.1 Diseased symptoms on leaf and fruit

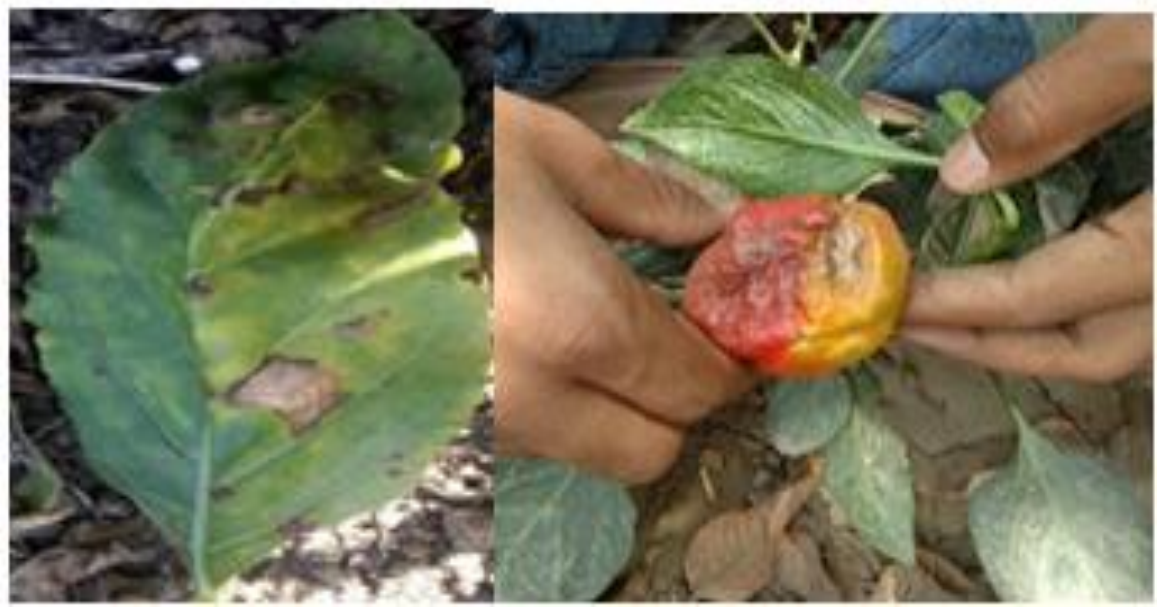

Fig.2 Pure form of C.capsici Microscopic view of C. capsici

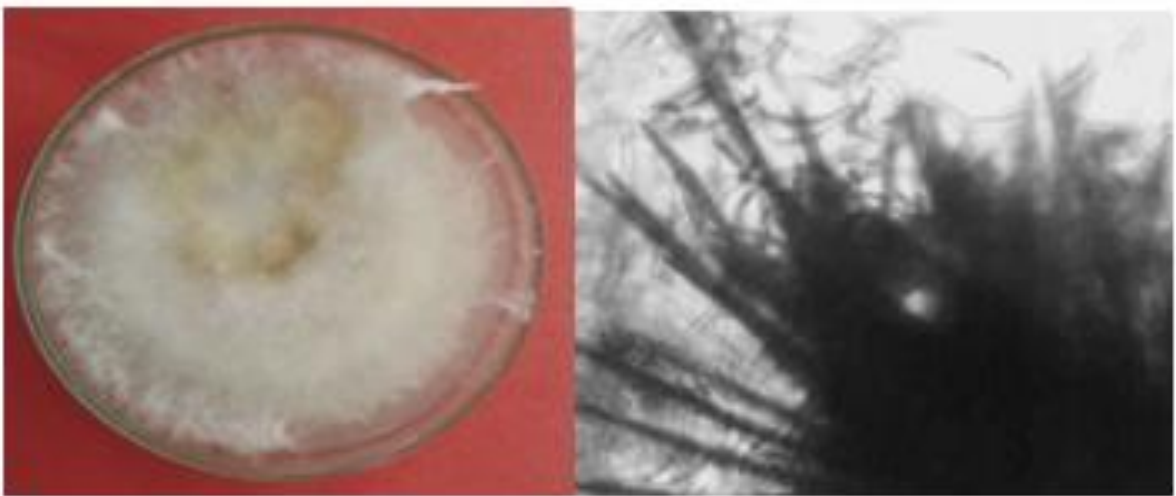

Fig.3

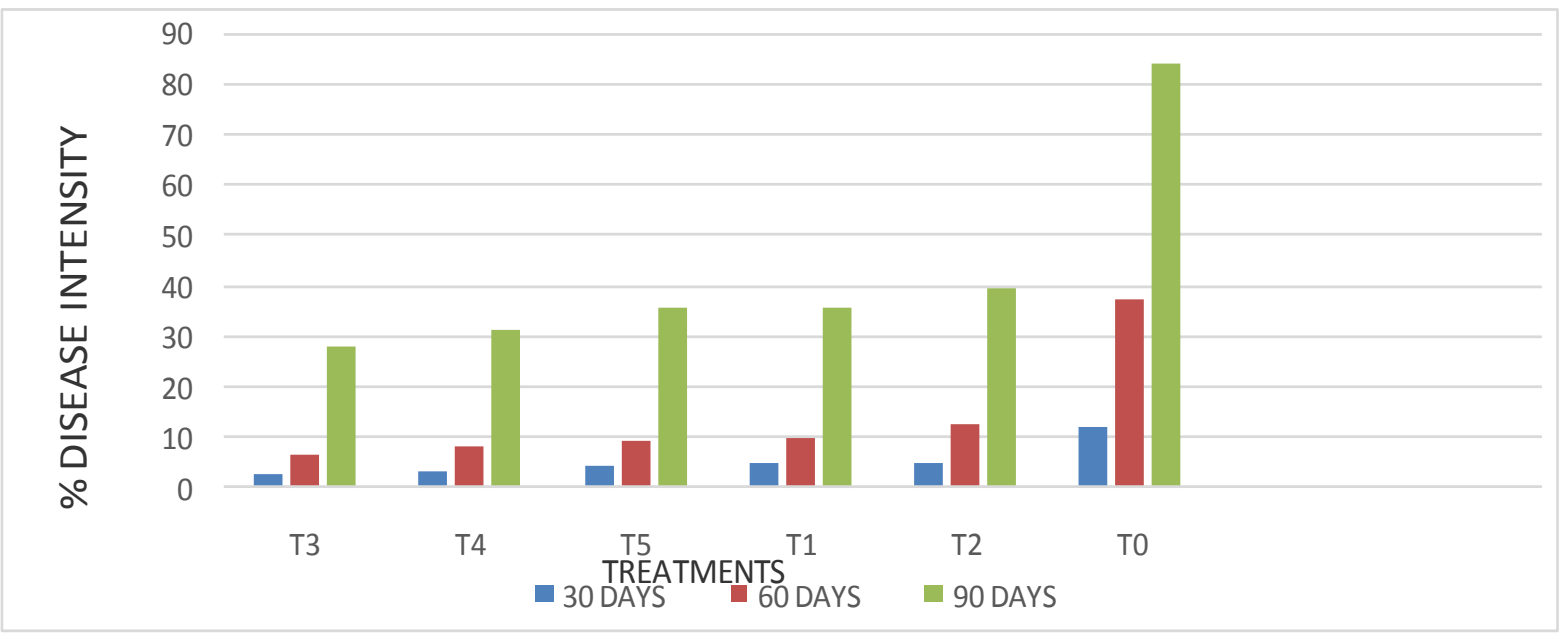


Fig.4

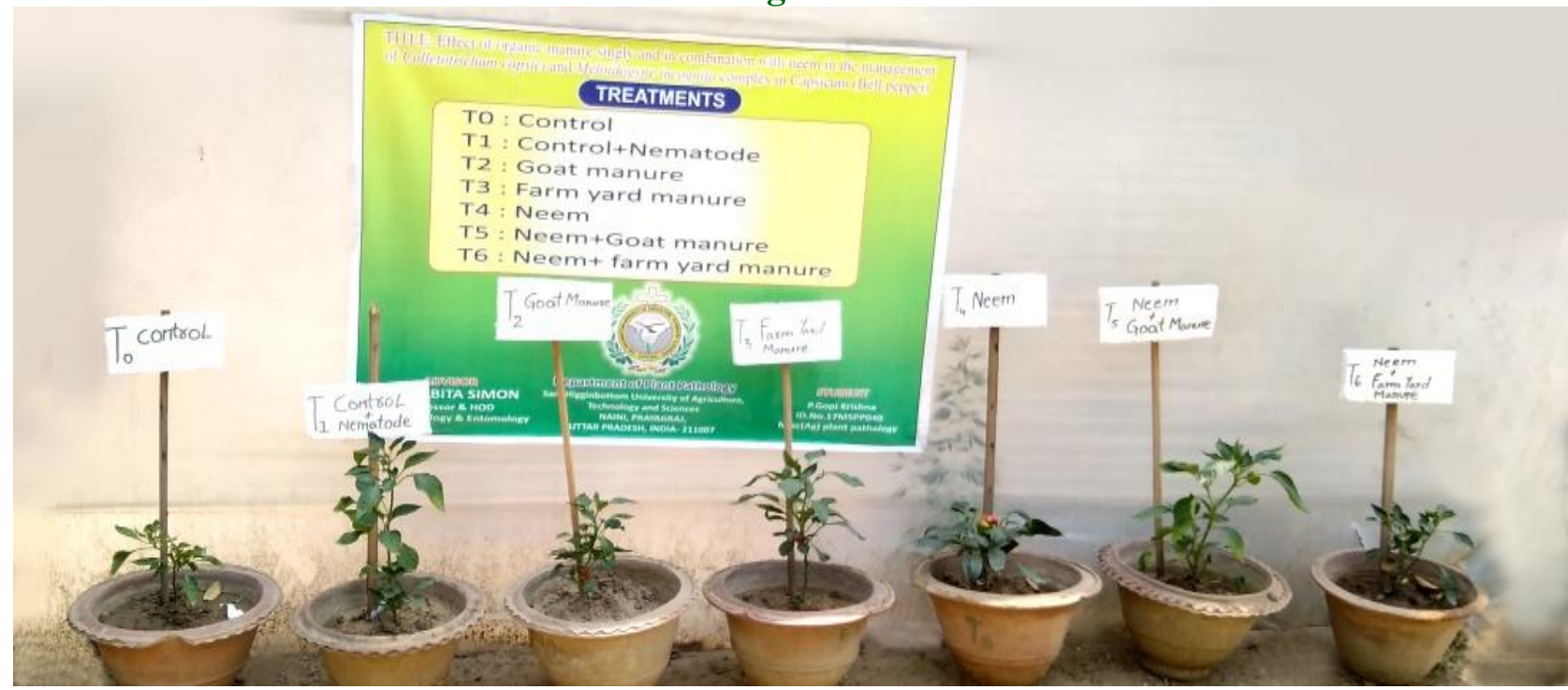

Fig.5

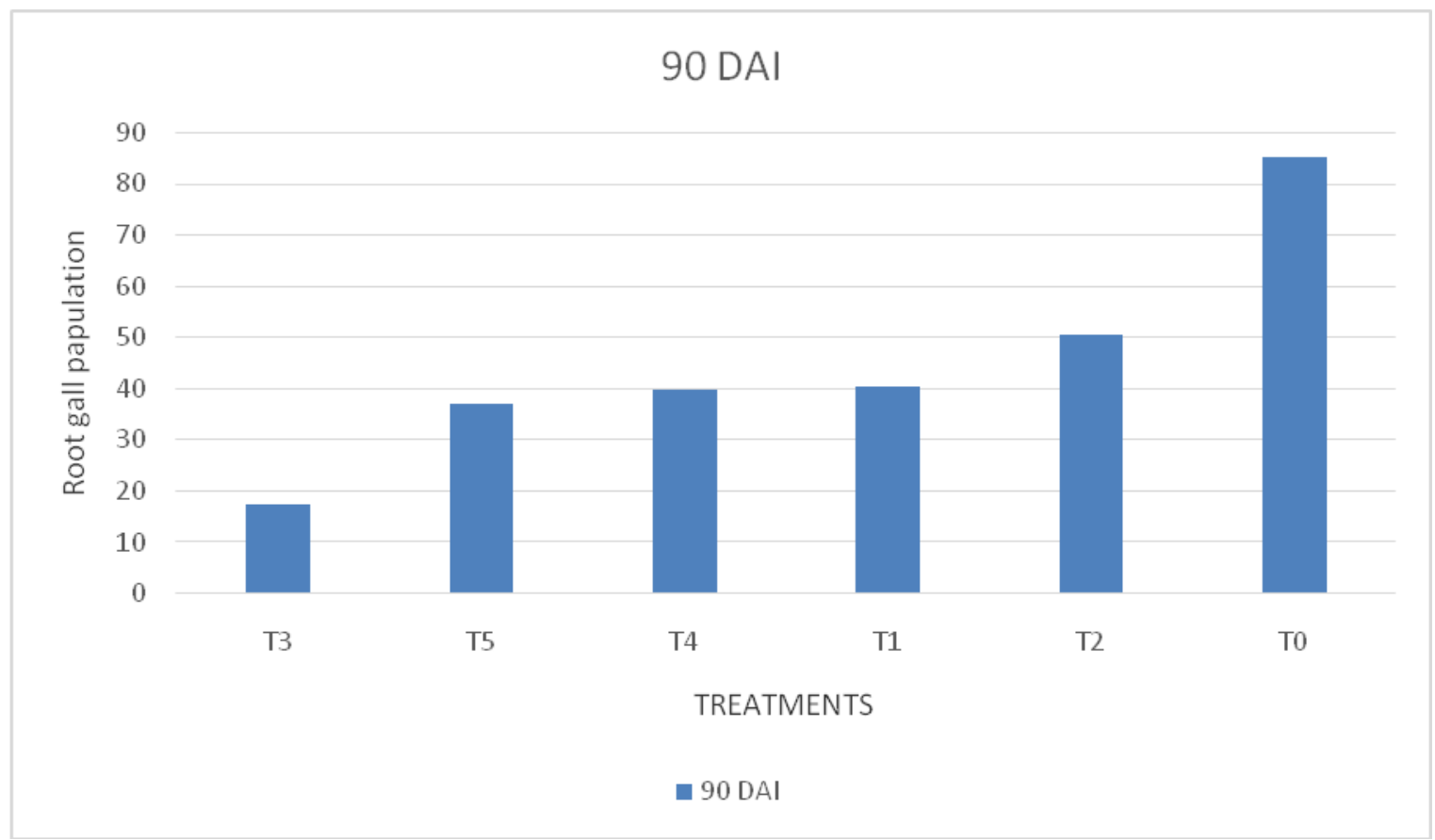


Fig.6 (A). Control (B). Goat manure (C). FYM (D). Neem (E). Neem+G.M (F). Neem+FYM Root galls population of M.incognita at $90 \mathrm{DAI}$
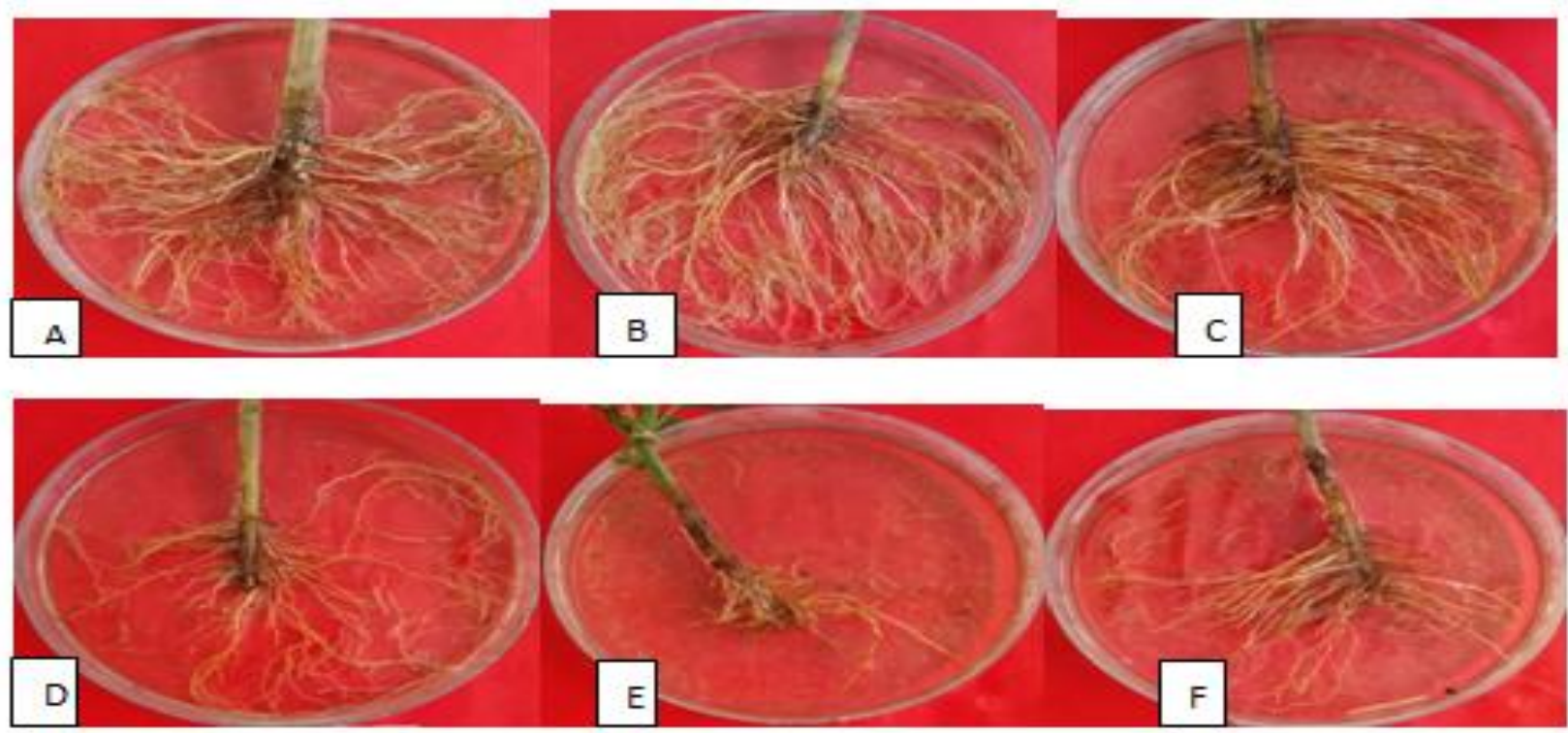

At 30 DAT the maximum reduction of disease incidence was found in $\mathrm{T}_{3}$-neem leaf manure (2.93) followed by $\mathrm{T}_{4}$-Neem+Goat manure (3.58), $\mathrm{T}_{5^{-}}$Neem+ FYM (4.37), $\mathrm{T}_{1^{-}}$Goat manure (4.73) and $\mathrm{T}_{2}$ - FYM (4.95). Where as $\left(\mathrm{T}_{4}, \mathrm{~T}_{5}, \mathrm{~T}_{3}, \mathrm{~T}_{2}, \mathrm{~T}_{1}\right)$ are not significantly different from each other. At 60 d.a.t. percentage disease incidence of C.capsici was significantly reduced in $\mathrm{T}_{3}$ - Neem leaf manure (6.46) followed by $\mathrm{T}_{4}$-Neem+ Goat manure (8.12), $\mathrm{T}_{5}$-Neem+ FYM (9.58)and $\mathrm{T}_{1}$ - Goat manure (9.92) as compared to $\mathrm{T}_{2^{-}} \mathrm{FYM}$ (12.74) and $\mathrm{T}_{0^{-}}$(37.62). At 90 d.a.i. percentage disease incidence were significantly reduced in $\mathrm{T}_{3}$ - Neem (27.98) and $\mathrm{T}_{4}$-Neem+ Goat manure (31.65) as compared with $T_{1}, T_{2}$, and $T_{5}$. Among the treatments $\left(T_{3}\right.$, $\left.\mathrm{T}_{4}\right)$ and $\left(\mathrm{T}_{5}, \mathrm{~T}_{1}, \mathrm{~T}_{2}\right)$ are not significant from each other.

Similarly findings have been reported by Sana et al., (2015) revealed that among the soil amendments, neem was found to be best in reducing disease intensity of the pathogen when compared with other treatments
The data presented in table 1.2 and depicted in figure 1.2 reveals the response of effect of organic manures on root gall population of Meloidogyne incognita under pot conditions. The result of 90 DAS indicates that all the treatments are significantly reduce the root gall population of capsicum compared with control. The treatments $\mathrm{T}_{3}$-Neem - (17.00) significantly reduced root gall population for mother organic amendments, However, the treatments $\mathrm{T}_{1^{-}}$Goat manure - (40.40), $\mathrm{T}_{4-}$ Neem+Goatmanure - (39.80), $\quad \mathrm{T}_{5^{-}}$ Neem+FYM- (37.00), significantly reduced from $\mathrm{T}_{2} \mathrm{FYM}$ - (50.40). Among the treatments $\left(\mathrm{T}_{1}, \mathrm{~T}_{4}\right.$ and $\left.\mathrm{T}_{5}\right)$ are not significantly differ from each other.

Maximum percentage of reduction over control was obtained is $\mathrm{T}_{3} \mathrm{Neem}+\mathrm{Nematode}-$ (79.29) andT $_{5}$ Neem+FYM+Nematode (56.47) followed by $\mathrm{T}_{4} \mathrm{G} . \mathrm{M}+\mathrm{Neem}+$ Nematode - (53.17), T $\mathrm{T}_{1}$ G.M+Nematode -(52.47) and $\mathrm{T}_{2}$ FYM+Nematode- (40.70).

In the present study among the different organic manures tested, Neem and 
Neem+FYM were found most effective in suppressing Meloidogyne incognita root galls population in capsicum. The neem based amendments were the most suppressive, recording zero nematode numbers at the end of the study. The application of neem products as soil amendments on fallow land may significantly reduce the number of plantparasitic nematodes before subsequent cropping (Kofi Agyarko and John Sackey 2005).

Similarly findings have been reported by Reddy et al., (1993) who revealed that, among the different soil amendments neem based amendments effectively used $50 \mathrm{~g}$ neem $/ \mathrm{kg}$ soil to contol root-knot nematodes were the most suppressive, in reducing the root galls population when compared with other amendments of treatments.

Based on the results it is concluded that Neem and Goat manure amended soil was proved to be most effective against disease intensity of Colletotrichum capsici, Neem and Neem+FYM were proved to be most effective against root-gall population of Meloidogyne incognita.

\section{References}

Agrios, G. N. (2005).Plant pathology. 5th Edn, Academic Press, San Diego. 922

Agyarko, K. and John, S. (2005). Nematode dynamics in a soil amended with neem leaves and poultry manure. Asian Journal of Plant Sciences.ISSN: 16823974.

Akhtar, M. (1999). Plant growth and nematode dynamics in response to soil amendments with neem products, urea and compost. Bioresource Technology. 69: 181-183.

Bird, A. F. (1960). The Inducement of Giant Cells byMeloidogyne javanica," Nematologica. vol. 8, pp. 8-10.
Bosland, P. W. and Votava, E.J.(2003).Peppers: Vegetable and Spice Capsicums. Center for Agriculture and Bioscience International.England.p.233.

Datar, V. V. (1995). Pathogenicity and effect of temperature on six fungi causing fruit rot of chilli. Indian Journal of Mycology and Plant Pathology.1995; 25:312-313.

Ekbote, S. D. (2001). Survey for chilli disease in Haveri district of Karnataka. Journal of Agricultural Sciences. 15:726-728.

Fugro, P. A. (2000). Role of organic pesticides and manures in management of some important chilli diseases.Journal of Mycology and Plant Pathology. 2000; 30(1):96-97.

Ghaderi, R., Kashi, L. and Karegar, A. (2012). The Nematodes of Iran (based on the published reports until 2011). Agricultural Education and Extension Publication. Tehran, Iran, 371 pp.

Giebel (1974).Biochemical mechanisms of plant resistance to nematodes: A review, - Journal of nematology.

Hadden, J. F. and Black, L. L.(1989).Anthracnose of pepper caused by Colletotrichum spp. Proc. Internat. Sympo.on Integrated Management Practices: Tomato and Pepper Production in the Tropics. Phytopathology.77: 641.

James, L. V. and Simon, S.(2013). Integrated Approach using Organic Manure and Botanical Extracts against Anthracnose (Colletotrichum capsici) of Chili (Capsicum annum L.)" M.Sc. (Ag.) Thesis, Department of Plant Pathology, SHIATS, Allahabad (211007) U. P.

Jepson, S. B. (1987) Identification of root knot nematodes (Meloidogyne species) Wallingford, UK: CAB International.

Kumar, M. A. and Bhaskaran, R.(2007). Tacties to manage disease problem in 
chilli: Spice India. 24-27.

Linu, M. S., Jisha, M. S. and Jisha, M. S.(2017). In vitro control of Colletotrichum capsici induced chilli anthracnose by fungicides and biocontrol agent. International Journal of Applied and Pure Science and Agriculture.3(5):27-33.

Rathore, B. S. (2006). Evaluation of bio efficacy of myclobutanil (Systhane $10 \% \mathrm{WP}$ ) against disease of chilli. Journal of Mycology and Plant Pathology. 36(1):74-76.

Reddy, P. P., Khan, P. M., Rao, M. S. and Ramaprasad, G. (1993). Management of root-knot nematodes infesting papaya by incorporation of some plant leaves. In: Chari, M.S. (Ed.) Botanical pesticides in integrated pest management: Proceedings of National symposium held in January 21-22, 1990 at Central Tobacco Research
Institute, Rajahmundry, India, pp: 421423.

Sana, N., Shoaib, A., Javaid, A. and Nafisa (2015). Effect of neem leaves as soil amendment on southern blight disease, growth and physiology of chilli. Pakisthan Journal of Phytopathology. Vol. 27.115-120.ISSN:1019-763.

Singh, R. R. and Shukla, P. (1988). Colletotrichum leaf blight of black gram. Farm Sciences Journal.3:97102.

Suji, H. S. and Raj, S. H. (2015).Efficacy of fish compost on management of chilli fruit rot caused by Colletotrichum capsici. African journal of biotechnology. 14(17):1493-1495.

Williamson, V. M. and Hussey, R. S. (1996). Nematode pathogenesis and resistance in plants. The Plant Cell. 8, 17351745.

\section{How to cite this article:}

Pillakathupu Gopi Krishna, Mullangi Pranitha and Sobita Simon. 2021. Effect of Organic Manures in the Management of Colletotrichum capsici and Meloidogyne incognita in Capsicum (Bell Pepper). Int.J.Curr.Microbiol.App.Sci. 10(05): 170-178. doi: https://doi.org/10.20546/ijcmas.2021.1005.023 